\title{
Risk of Late-Onset Hypogonadism (Andropause) in Brazilian Men over 50 Years of Age with Osteoporosis: Usefulness of Screening Questionnaires
}

\begin{abstract}
Objective: To analyze the relative risk of late-onset hypogonadism in men with osteoporosis and the usefulness of screening questionnaires. Methods: We correlated the Aging Male's Symptoms (AMS), Androgen Deficiency in Aging Male (ADAM) and International Index of Erectile Function (IIEF-5) questionnaires and the laboratory diagnosis of hypogonadism in 216 men aged 50-84 years ( 110 with osteoporosis and 106 with normal bone density, paired by age and ethnicity). Results: Hypogonadism presented in $25 \%$ of the osteoporotic and in $12.2 \%$ of normal bone density men (OR 2.08; IC95\%: 1.14-3.79) and was associated with ADAM first question (low libido, $p=0.013$ ). Levels of TT below $400 \mathrm{ng} / \mathrm{dl}$ correlated with an AMS score above 26 ( $p=0.0278$ ). IIEF-5 showed no correlation with testosterone levels. Conclusion: Hypogonadism was 2.08 times more prevalent in osteoporotic men. The symptom that best correlated with late-onset hypogonadism was low libido (ADAM 1 positive). (Arq Bras Endocrinol Metab 2008; 52/9:1439-1447)
\end{abstract}

Keywords: Andropause; Screening questionnaires; Testosterone; Late-onset hypogonadism; Male osteoporosis

\section{RESUMO}

Risco Relativo de Hipogonadismo Tardio (Andropausa) em Brasileiros com Mais de 50 Anos com Osteoporose e a Utilidade de Questionários de Triagem.

Objetivos: Avaliar o risco relativo de hipogonadismo tardio em homens com osteoporose e a utilidade de questionários de triagem. Métodos: Correlacionamos a pontuação dos questionários Aging Male's Symptoms (AMS), Androgen Deficiency of the Aging Male (ADAM) e International Index of Erectile Function (IIEF-5) com dosagens de testosteronas em 216 homens entre 50 e 84 anos (110 com osteoporose e 106 com densidade óssea normal, pareados por idade e etnia). Resultados: Hipogonadismo ocorreu em $25 \%$ dos osteoporóticos e em 12,2\% dos com densidade óssea normal (RR 2,08; IC95\%: 1,143,79 ) e esteve associado à pergunta 1 do ADAM (diminuição de libido, $p=$ $0,013)$. Testosterona total $<400 \mathrm{ng} / \mathrm{dL}$ associou-se a AMS $>26(p=0,0278)$. Disfunção erétil, avaliada pelo IIEF-5, não se correlacionou com dosagens de testosteronas. Conclusão: Hipogonadismo foi 2,08 vezes mais prevalente em homens com osteoporose e esteve associado à diminuição da libido (ADAM 1 positivo). (Arq Bras Endocrinol Metab 2008; 52/9:1439-1447)

Descritores: Andropausa; Questionários de triagem; Testosterona; Hipogonadismo masculino tardio; Osteoporose masculina

\section{INTRODUCTION}

he process of aging in men involves modifications in sexual steroid levels, with psycho-physical repercussions of variable intensity. In the serum of

\section{original article}

\author{
Ruth Clapauch \\ Daniel Jorge de Castro Braga \\ Lizanka Paola Marinheiro \\ SALO BUKSMAN \\ Yolanda SCHRANK
}

Division of Female Endocrinology and Andrology, Endocrinology Sector, Hospital da Lagoa (RC, DJCB); Instituto Fernandes Figueira, Fiocruz (LPM); Instituto Nacional de Traumato Ortopedia (INTO), Ministry of Health (SB); Diagnósticos da América (YS); Rio de Janeiro, RJ, Brazil.

Received in 18/6/2008 Acepted in 23/10/2008 
young men, $54 \%$ of circulating testosterone is bound nonspecifically to albumin (low affinity binding) and $44 \%$ specifically to sex hormone binding globulin (SHBG, high affinity binding), while 1 to $3 \%$ is unbound, known as free testosterone (FT). FT and testosterone bound to albumin constitute the category of bioavailable testosterone (BT), as both have biological activity (1). As men age, there is a gradual reduction in the total testosterone serum concentration and a progressive increase in $\mathrm{SHBG}$, so low androgen levels are best demonstrated by FT and BT dosages (2). "Gold standard" methods of assessment are equilibrium dialysis (for FT), and ammonium sulfate precipitation (for $\mathrm{BT}$ ). Both methods are expensive, difficult to perform, and largely inaccessible to most clinicians. An alternative method calculates FT and BT via a formula that uses total concentration of serum testosterone, SHBG and albumin as input variables $(2,3)$.

Aging men with low androgen levels may experience decreased libido, with or without sexual dysfunction, as well as low muscle strength, psychological changes, mainly depression and increased risk of osteoporosis (4-7). This array of psycho-somatic-sexual symptoms is referred to by many names, such as Late-onset Hypogonadism ( $\mathrm{LOH}$ ) or Andropause.

By definition, $\mathrm{LOH}$ is a clinical and biochemical syndrome associated with aging and characterized by a set of typical symptoms, as well as testosterone deficiency (8). However, these symptoms are not specific enough to be considered pathognomonic, which makes $\mathrm{LOH}$ difficult to clinically distinguish from aging.

Tools were recently developed to screen men exhibiting these general symptoms for a suite of other possible deficiencies, so that the chance of making the correct clinical diagnosis could be improved. These tools include the Androgen Deficiency of the Aging Male (ADAM) questionnaire (9), and the Aging Male Symptoms (AMS) scale (10). A frequent symptom associated with hypogonadism is erectile dysfunction (ED). The International Index of Erectile Function is a well-established tool for screening men with ED (11).

Men with osteoporosis represent a group with high risk of LOH (5). The current study sought to: (i) determine the relative risk of hypogonadism in men over 50 years of age in the city of Rio de Janeiro, with osteoporosis compared to men with normal bone density of the same age and ethnicity; (ii) evaluate the usefulness of the above questionnaires as screening tools for $\mathrm{LOH}$, correlating their scores to the testosterone levels used for the laboratory diagnosis of hypogonadism.

\section{SUBJECTS AND METHODS}

\section{Patients}

The population analyzed in this paper was recruited from the Men's Osteoporosis Detection Program of the Instituto Nacional de Traumato-Ortopedia (INTO). The INTO program is a cross-sectional study that aims to determine the prevalence of male osteoporosis in the city of Rio de Janeiro. Up to January 2005, about 800 men voluntarily sought out the program after it was advertised in the midia (radio, newspaper and TV) that a free osteoporosis evaluation was being offered for all men over 50 years of age. Every men who spontaneously presented at INTO had a lumbar spine and hip bone densitometry performed.

Men diagnosed with osteoporosis $(n=132)$ were contacted by telephone, telegram or letter to inquire whether they would participate in a complementary evaluation of male health that addressed sexual hormones, which would be performed at the Hospital da Lagoa. One hundred and ten men (81\%) who had a diagnosis of osteoporosis through the INTO program accepted this invitation. In order to establish the relative risk of hypogonadism in osteoporotic men, a group of 106 men with normal bone densitometry from the same INTO program, matched by ethnicity and age, was also asked to participate.

\section{Study Design}

This cross-sectional study was designed to determine the prevalence of hypogonadism in men over 50 years of age who presented osteoporosis and normal bone mineral density; and to correlate laboratory and clinical data, through the responses to $\mathrm{LOH}$ screening questionnaires.

\section{Data Collection}

Patients were questioned individually about their medical history, with emphasis on morbidities such as genital surgery, drug use that could interfere with the synthesis or action of sexual hormones, depression and current use of anti-depressants. A general physical exam was performed, including the genitals, excluding prostate rectal exam.

Three questionnaires were given to each subject to determine the prevalence of signs and symptoms of male hypogonadism and erectile dysfunction (AMS, ADAM and IIEF-5). 
During the first medical exam, the Aging Male's Symptoms (AMS) scale questionnaire was used. This scale was created to screen for male hormone alterations, not to provide a definitive diagnosis (12). Each patient received a sheet containing the AMS questionnaire (Figure 1), which a doctor read aloud to a group of four to six patients. Subjects recorded their responses on a paper with a certain degree of privacy, such that each patient could not read the answers of the others.
The AMS is a Health Related Quality of Life scale (HRQOL) consisting of 17 questions, which measures complaints and quality of life issues related to health. The questionnaire has been translated into 14 languages, including Portuguese (10). The AMS score increases point by point, indicating increasing severity, in patients with: "no complaints" (17-26 points), "mild" (27-36 points), "moderate" (37-49 points), and "severe" ( $\geq 50$ points) complaints. The total score is di-

\begin{tabular}{|c|c|c|c|c|c|c|}
\hline Symptoms & $\begin{array}{c}\text { None } \\
1\end{array}$ & $\begin{array}{c}\text { Mildm } \\
2\end{array}$ & $\begin{array}{c}\text { Moderate } \\
3\end{array}$ & $\begin{array}{c}\text { Severe } \\
4\end{array}$ & $\begin{array}{l}\text { extremely } \\
\text { severe } 5\end{array}$ & $\begin{array}{l}\text { Score } \\
\quad=\end{array}$ \\
\hline $\begin{array}{l}\text { 1. Decline in your feeling of general well-being (general state of } \\
\text { health, subjective feeling) }\end{array}$ & $\square$ & $\square$ & $\square$ & $\square$ & $\square$ & \\
\hline $\begin{array}{l}\text { 2. Joint pain and muscular ache (lower back pain, joint pain, pain in } \\
\text { a limb, general back ache) }\end{array}$ & $\square$ & $\square$ & $\square$ & $\square$ & $\square$ & \\
\hline $\begin{array}{l}\text { 3. Excessive sweating (unexpected / sudden episodes of sweating, } \\
\text { hot flushes independent of strain) }\end{array}$ & $\square$ & $\square$ & $\square$ & $\square$ & $\square$ & \\
\hline $\begin{array}{l}\text { 4. Sleep problems (difficulty in falling asleep, difficulty in sleeping } \\
\text { through, waking up early and feeling tired, poor sleep, } \\
\text { sleeplessness) }\end{array}$ & $\square$ & $\square$ & $\square$ & $\square$ & $\square$ & \\
\hline 5. Increased need for sleep, often feeling tired & $\square$ & $\square$ & $\square$ & $\square$ & $\square$ & \\
\hline $\begin{array}{l}\text { 6. Irritability (feeling aggressive, easily upset about little things, } \\
\text { moody) }\end{array}$ & $\square$ & $\square$ & $\square$ & $\square$ & $\square$ & \\
\hline 7. Nervousness (inner tension, restlessness, feeling fidgety) & $\square$ & $\square$ & $\square$ & $\square$ & $\square$ & \\
\hline 8. Anxiety (feeling panicky) & $\square$ & $\square$ & $\square$ & $\square$ & $\square$ & \\
\hline $\begin{array}{l}\text { 9. Physical exhaustion / lacking vitality (general decrease in } \\
\text { performance, reduced activity, lacking interest in leisure activities, } \\
\text { feeling of getting less done, of achieving less, of having to force } \\
\text { oneself to undertake activities) }\end{array}$ & $\square$ & $\square$ & $\square$ & $\square$ & $\square$ & \\
\hline 10. Decrease in muscular strength (feeling of weakness) & $\square$ & $\square$ & $\square$ & $\square$ & $\square$ & \\
\hline $\begin{array}{l}\text { 11. Depressive mood (feeling down, sad, on the verge of tears, lack } \\
\text { of drive, mood swings, feeling nothing is of any use) }\end{array}$ & $\square$ & $\square$ & $\square$ & $\square$ & $\square$ & \\
\hline 12. Feeling that you have passed your peak & $\square$ & $\square$ & $\square$ & $\square$ & $\square$ & \\
\hline 13. Feeling burnt out, having hit rock-bottom & $\square$ & $\square$ & $\square$ & $\square$ & $\square$ & \\
\hline 14. Decrease in beard growth & $\square$ & $\square$ & $\square$ & $\square$ & $\square$ & \\
\hline 15. Decrease in ability/frequency to perform sexually & $\square$ & $\square$ & $\square$ & $\square$ & $\square$ & \\
\hline 16. Decrease in the number of morning erections & $\square$ & $\square$ & $\square$ & $\square$ & $\square$ & \\
\hline $\begin{array}{l}\text { 17. Decrease in sexual desire/libido (lacking pleasure in sex, lacking } \\
\text { desire for sexual intercourse }\end{array}$ & $\square$ & $\square$ & $\square$ & $\square$ & $\square$ & \\
\hline Do you have any other major symptoms? & Yes $\square$ & No $\square$ & If Yes & please & lescribe: & \\
\hline \multicolumn{7}{|l|}{ Evaluation } \\
\hline $\begin{array}{l}\text { Score } \\
\text { Severity of symptoms }\end{array}$ & $\begin{array}{l}17-26 \\
\text { none }\end{array}$ & $\begin{array}{l}27-36 \\
\text { mild }\end{array}$ & $\begin{array}{l}37-49 \\
\text { moderate }\end{array}$ & $\begin{array}{l}>50 \\
\text { severe }\end{array}$ & & \\
\hline
\end{tabular}

Figure 1. The Aging Males' Symptoms (AMS) scale - Which of the following symptoms apply to you at this time? Please, mark the appropriate box for each symptom. For symptoms that do not apply, please mark "none" (12). 
vided by three sub-scales: sexual, (questions 12 to 14 and 17), psychological (questions 6 to 9 and 11) and somato-vegetative (questions 1 to 5,10 and 13 ). The total score and not the sub-scales should be used, with a cut-off $\geq 27$ points (13). Heinemann et al.demonstrated that the AMS scale has a sensitivity of $73.6 \%$ and specificity of $70.4 \%$ for the improvement after androgen replacement therapy (14).

During the second medical exam, the St. Louis University questionnaire, also known as Androgen Deficiency of the Aging Male (ADAM), was given to the subjects (Figure 2) (9). Ten symptoms commonly observed in men with low bioavailable testosterone are assessed in the ADAM questionnaire. Affirmative answers to questions 1 or 7 or to any other three questions suggest hypogonadism. The ADAM questionnaire demonstrated a sensitivity of $88 \%$ and a specificity of $60 \%$ in men (9). This test has not yet been validated in Brazil. As an alternative way allowing us to use this questionnaire, the answers given by subjects from our sample, without osteoporosis or hypogonadism, were planned to be analyzed in separate. A non-statistical difference in testosterone values between normal subjects with positive and negative results for the ADAM questionnaire could empower us to use it for the study.

The IIEF- 5 questionnaire, an abbreviated version of the International Index of Erectile Function (IIEF) to evaluate erectile function (15), was also given during the second medical exam. The IIEF- 5 has a maximum score of 25 , and was developed by Rosen et al. (Figure 3 )

1. Do you have a decrease in libido (sex drive)?
2. Do you have a lack of energy?
3. Do you have a decrease in strength and/or
endurance?
4. Have you lost height?
5. Have you noticed a decreased enjoyment of life?
6. Are you sad and/or grumpy?
7. Are your erections less strong?
8. Have you noted a recent deterioration in your ability to
play sports?
9. Are you falling asleep after dinner?
10. Has there been a recent deterioration in your work
performance?
Affirmative answers to questions 1 or 7, or to any other
three questions provide a positive result on the ADAM
questionnaire

Figure 2. ADAM's Questionnaire - Answer "Yes" or "No" (11).
1) How do you rate your confidence that you could keep an erection?

(1) Very low (2) low (3) Moderate (4) High (5) Very high

(2) When you had erections with sexual stimulation, how often were your erections hard enough for penetration (entering your partner)?

(1) Almost never or never (2) A few times (much less than half the time) (3) Most times (about half the time) (4) Much more than half the time (5) Almost always

3) During sexual intercourse, how often were you able to maintain your erection after you had penetrated (entered) your partner?

(1) Almost never or never (2) A few times (much less than half the time) (3) Most times (about half the time) (4) Much more than half the time (5) Almost always

4) During sexual intercourse, how difficult was it to maintain your erection to completion of intercourse?

(1) Extremely difficult (2) Very difficult (3) Difficult (4) Slightly difficult (5) Not difficult

5) When you attempted sexual intercourse, how often was it satisfactory for you?

(1) Almost never or never (2) A few times (much less than half the time) (3) Most times (about half the time) (4) Much more than half the time (5) Almost always

Result: $\leq 21$ has some degree of erectile dysfunction

Figure 3. Questionnaire IIEF-5 - Each question has 5 possible responses. Circle the number that best describes your own situation over the past six months. Select only one answer for each question (13).

(11). Scores above 21 are considered normal and without ED. Lower scores indicate ED of increasing severity: mild ED ( 17 to 21 ), mild to moderate ED (12 to 16), moderate ED (8 to 11 ), and severe ED (5 to 7 ). Using a cut-off of $<22$ points, the IIEF- 5 demonstrated a sensitivity of $98 \%$ and a specificity of $88 \%$ for the detection of the presence and severity of ED (11). This test was validated in Brazil by Rhoden et al. (16).

\section{Laboratory measurements}

Between the first and second medical exams, blood samples were collected at the laboratory of the Instituto Fernandes Figueira, between 8:30 and 10:00 in the morning, for measurement of: (i) general parameters used for detecting causes of osteoporosis; (ii) TSH for the exclusion of hypothyroidism as a clinical differential diagnosis of LOH; (iii) albumin. Part of the collected blood sample was separated and sent to the Diagnósticos 
da América Laboratory, for measurement of total testosterone (TT) and SHBG. Free testosterone and BT were then calculated from the dosages of TT, SHBG and albumin with the formula of Vermeulen (17) through the website http://www.issam.ch/freetesto.htm.

Laboratory hypogonadism was defined as having cFT $<6.5 \mathrm{ng} / \mathrm{dl}$ in two samples collected at different times $(5,18$, and 19$)$.

During the second medical exam, the patient was informed about the results of his blood tests. If the calculated free testosterone $(\mathrm{cFT})$ value was $<6.5 \mathrm{ng} / \mathrm{dl}$, a second blood sample collection was scheduled to take place at least one month after the first, in the laboratory of the Instituto Fernandes Figueira. The total testosterone and SHBG blood samples were once again sent to the Diagnósticos da América Laboratory for new calculations of free and bioavailable testosterone. Folliclestimulating hormone (FSH), Luteinizing hormone $(\mathrm{LH})$, and prolactin were measured at the Instituto Fernandes Figueira in order to exclude secondary causes of hypogonadism.

Total testosterone was measured by chemiluminescence, using an automatic kit from Advia Centaur (Bayer Diagnostics), analytical sensitivity of $100 \mathrm{ng} / \mathrm{dl}$, and reference values in men of 241 to $827 \mathrm{ng} / \mathrm{dl}$. SHBG was also measured by chemiluminescence, using the Immulite 1000 kit (Siemens), which has an analytical sensitivity of $0.2 \mathrm{nmol} / 1$ and reference values in men of 13 to $71 \mathrm{nmol} / \mathrm{l}$. Albumin concentrations were determined by colorimetric spectrophotometry, with a kit from Targa BT Plus (Wiener Lab.), and reference values of 3.5 to $5.5 \mathrm{~g} / \mathrm{dl}$. The $\mathrm{FSH}, \mathrm{LH}$ and prolactin concentrations were measured by chemiluminescence, with the VIDAS kit (Biolab Merieux). The male reference values used were: FSH (0.9-15 UI/L), LH (1.3$13 \mathrm{UI} / \mathrm{L})$, prolactin $(<15 \mathrm{ng} / \mathrm{ml})$.

The following factors were then analyzed: total AMS score, affirmative responses to questions 1 or 7 or to any other three questions of the ADAM questionnaire, and the total IIEF-5 score. Correlations were constructed between these scores and laboratory hypogonadism using TT levels, as well as FT and BT levels, which were calculated by Vermeulen's formula (17).

\section{Statistical Analysis}

The statistical analysis were done with the Student $\mathrm{t}$ test for continuous variables in the Graphpad Prism version 3.00 for Windows program (Graphpad Software, San Diego, CA, USA). For categoric variables, the chi-square test by Mantel-Haenszel was performed in the Epi-info 6.04 program (CDC, Atlanta). The significance level was set at $\mathrm{p}<0.05$.

\section{Ethical aspects}

The research objectives were explained to the men who attended the first medical exam in small groups, and each subject signed an informed-consent document approved under the Ethics Committee protocol.

\section{RESULTS}

Forty-one men (19\% of the total sample) were diagnosed with hypogonadism by laboratory criteria ( 2 samples of $\mathrm{cFT}<6.5 \mathrm{ng} / \mathrm{dl}$ ): 28 in the osteoporosis group $(25 \%)$ and 13 in the control group (12.2\%). The OR for hypogonadism in osteoporotic men was 2.08 (IC95\%:1.14-3.79). None of the subjects had hypogonadism secondary to hyperprolactinemia or pituitary insufficiency. Causes of osteoporosis that could mask the clinical diagnosis of hypogonadism were not demonstrated by the general exams.

When the AMS and ADAM questionnaires were used as screening tools, the percentages of subjects who exhibited symptoms compatible with late-onset hypogonadism were determined to be $84 \%$ (179 patients) and $60 \%$ (128 patients), respectively

With regard to the AMS questionnaire, total scores equal to or greater than 27 showed an association only with TT levels below $400 \mathrm{ng} / \mathrm{dl}$; no association was found with $\mathrm{cBT}$ or $\mathrm{cFT}$ (Table 1 ).

The answers given by 91 subjects from our sample, with normal bone density and without hypogonadism, to the ADAM questionnaire were analyzed. The only criterion out of all those assessed that could be "validated" was the ADAM first question, such that there was no statistical difference between the percentages of subjects with a positive and a negative result for this question $(54,94$ and $45,05 \%$ respectively, $\mathrm{p}=0.18)$.

There was a significant association between an affirmative answer to ADAM question number 1 and a laboratory diagnosis of hypogonadism, as well as levels of cFT, cBT and TT comparable to those seen in patients with hypogonadism (Table 2). Among hypogonadal 
Table 1. Comparisons of AMS score $\geq 27$ with measurements of calculated free, bioavailable and total testosterone.

\begin{tabular}{|c|c|c|c|c|c|c|}
\hline Hormone samples & AMS $\geq 27 \mathrm{n} /$ total $(\%)$ & AMS $<27 \mathrm{n} /$ total $(\%)$ & OR & $95 \% \mathrm{Cl}$ & Sensitivity (\%) & Specificity (\%) \\
\hline $\begin{array}{l}2 \text { cFT samples } \\
<6.5 \mathrm{ng} / \mathrm{dl}^{*}\end{array}$ & $35 / 41(85.4)$ & $6 / 41(14.6)$ & 1.21 & $0.63-4.45$ & 85.4 & 19.9 \\
\hline $\begin{array}{l}1 \mathrm{cFT} \text { sample } \\
<6.5 \mathrm{ng} / \mathrm{dl}\end{array}$ & $51 / 58(87.9)$ & $14 / 58(22.1)$ & 1.69 & $0.65-4.54$ & 87.9 & 18.8 \\
\hline $\begin{array}{l}1 \text { cBT sample } \\
<140 \mathrm{ng} / \mathrm{dl}\end{array}$ & $42 / 48(87.5)$ & $6 / 48(22.5)$ & 1.52 & $0.55-4.39$ & 87.5 & 17.9 \\
\hline $\begin{array}{l}1 \mathrm{TT} \text { sample } \\
<400 \mathrm{ng} / \mathrm{dl}\end{array}$ & $46 / 49(93.9)$ & $3 / 49(6.1)$ & 3.69 & $1.01-15.89$ & 93.9 & 19.4 \\
\hline
\end{tabular}

Number of patients who answered the AMS questionnaire $=214 . \mathrm{OR}=$ odds ratio; $\mathrm{Cl}=$ confidence interval; $\mathrm{T}$ = total testosterone; $\mathrm{CFT}=\mathrm{calculated}$ free testosterone; $\mathrm{CBT}=$ calculated bioavailable testosterone; * Laboratory diagnosis of hypogonadism.

Table 2. Comparison of answer to ADAM question 1: "Do you have a decrease in libido (sex drive)?" and calculated free, bioavailable and total testosterone levels.

\begin{tabular}{lcccccc}
\hline Hormone samples & Yes n/total (\%) & No n/total (\%) & OR & 95\% Cl & Sensitivity (\%) & Specificity (\%) \\
\hline 2 cFT samples < 6.5 ng/dl* & $31 / 40(77.5)$ & $9 / 40(22.5)$ & 2.70 & $1.15-6.52$ & 77.5 & 43.9 \\
\hline 1 cFT sample < $6.5 \mathrm{ng} / \mathrm{dl}$ & $43 / 57(75.4)$ & $14 / 57(24.6)$ & $\mathbf{2 . 5 7}$ & $1.24-5.37$ & 75.4 & 45.5 \\
1 cBT sample < $140 \mathrm{ng} / \mathrm{dl}$ & $34 / 46(73.9)$ & $12 / 46(26.1)$ & $\mathbf{3 . 2 5}$ & $1.01-4.86$ & 73.9 & 43.7 \\
\hline 1 TT sample < $400 \mathrm{ng} / \mathrm{dl}$ & $35 / 48(72.9)$ & $13 / 48(27.1)$ & $\mathbf{2 . 0 8}$ & $0.97-4.49$ & 72.9 & 43.6 \\
\hline
\end{tabular}

Number of patients who answered the AMS questionnaire $=213 ; \mathrm{OR}=$ odds ratio; $\mathrm{Cl}=$ confidence interval; $\mathrm{TT}=$ total testosterone; $\mathrm{cFT}=\mathrm{calculated}$ free testosterone: $\mathrm{CBT}=$ calculated bioavailable testosterone

Table 3. Comparison of the prevalence of positive answers to question 1 of the ADAM questionnaire with cFT values.

\begin{tabular}{lcccc}
\hline & \multicolumn{2}{c}{ ADAM 1 test } & \multicolumn{2}{l}{ Negative } \\
\hline & \multicolumn{2}{c}{ Positive } & \multicolumn{2}{c}{ Neg } \\
CFT $(\mathrm{ng} / \mathrm{dl})$ & $\mathrm{n}$ & $\%$ & $\mathrm{n}$ & $\%$ \\
$<4$ & 5 & 100 & 0 & 0 \\
$\geq 4$ and $<5$ & 10 & 76.9 & 3 & 23.1 \\
$\geq 5$ and $<6.5$ & 16 & 72.7 & 6 & 27.3 \\
\hline Total & 31 & 77.5 & 9 & 22.5 \\
\hline
\end{tabular}

$\mathrm{CFT}=$ calculated free testosterone

men, an inverse relationship was observed between cFT values and ADAM 1 positive status (Table 3 ). No correlations were detected between question 7 or the total ADAM score and levels of TT, cFT or cBT.

The IIEF- 5 questionnaire revealed no correlation between laboratory-defined hypogonadism and ED $(\mathrm{p}=0.269)$. There was no difference between TT, cFT or cBT levels among men with IIEF- $5<22$ or $\geq 22$. The correlations between IIEF- 5 scores and hormone levels were very weak: TT: -0.04393 , cFT: -0.05049 and $\mathrm{CBT}$ : -0.05077 .

However, 147 men ( $74 \%$ of the subjects) complained of some degree of ED, expressed by IIEF- 5 score $<22$. Significant differences were found between the percentages of subjects without any ED seen in each age group: $41.4 \%$ in the group of 50 to 59 years old, compared to $30.3 \%$ in the group of 60 to 69 years old and $16.3 \%$ in the group of 70 or older. Severe ED was more prevalent in men of 70 years or older ( $\mathrm{p}=0.006$ ), while in the 50 to 59 group, $31 \%$ had mild $\mathrm{ED}, 17.2 \%$ mild to moderate, $6.9 \%$ moderate and $3.4 \%$ severe. These differences were statistically significant $(\mathrm{p}=0.0002)$ (Table 4$)$.

\section{DISCUSSION}

Most of the articles published in the scientific literature agree that hypogonadism should be defined with biochemical as well as functional criteria $(8,20$, and 21$)$. The functional criteria are typically assessed by questio- 
Table 4. Prevalence of erectile dysfunction (ED) sorted by age.

\begin{tabular}{|c|c|c|c|c|c|c|c|c|c|}
\hline \multirow[b]{2}{*}{ IIEF-5 score } & \multicolumn{2}{|c|}{$\leq 59$ years } & \multicolumn{2}{|c|}{$60-69$ years } & \multicolumn{2}{|c|}{$\geq 70$ years } & \multicolumn{2}{|c|}{ Total } & \multirow[t]{2}{*}{$p$-value ${ }^{1}$} \\
\hline & $\mathrm{N}$ & $\%$ & $N$ & $\%$ & $\mathrm{~N}$ & $\%$ & $\mathrm{~N}$ & $\%$ & \\
\hline $22-25$ (no ED) & 12 & 41.4 & 27 & 30.3 & 13 & 16.3 & 52 & 26.3 & 0.0088 \\
\hline $17-21$ (mild) & 9 & 31.0 & 20 & 22.5 & 21 & 26.3 & 50 & 25.3 & 0.6311 \\
\hline $\begin{array}{l}\text { 12-16 } \\
\text { (mild to moderate) }\end{array}$ & 5 & 17.2 & 19 & 21.3 & 11 & 13.8 & 35 & 17.7 & 0.432 \\
\hline $8-11$ (moderate) & 2 & 6.9 & 9 & 10.1 & 12 & 15.0 & 23 & 11.6 & 0.424 \\
\hline$\leq 7$ (severe) & 1 & 3.4 & 14 & 15.7 & 23 & 28.8 & 38 & 19.2 & 0.006 \\
\hline Total & 29 & 100.0 & 89 & 100.0 & 80 & 100.0 & 198 & 100.0 & \\
\hline$p$-value ${ }^{2}$ & & 0.0002 & & 0.00320 & & 0.03 & & & \\
\hline
\end{tabular}

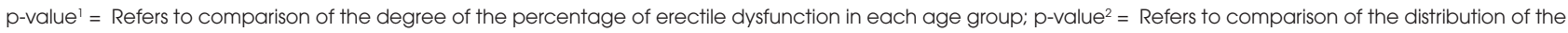
degrees of erectile dysfunction in each age group.

nnaires, although the sensitivity and specificity of these tests should be individualized for each culture, to be proven useful. The biochemical criteria requires two measurements of calculated free and bioavailable testosterone, as demonstrated in our study.

Despite the great sensitivity for testosterone levels compatible with hypogonadism ( 88 to $94 \%$ ), the AMS scale did not prove to be valid as an exclusive tool for screening, as shown by the low specificity we detected (18 to $19 \%$ ). Using a cutoff of score $\geq 27$, the only correlation found was with TT $<400 \mathrm{ng} / \mathrm{dl}$ (OR: 3.69; 95\% CI: 1.01-15.89), a level that is not diagnostic of hypogonadism, but rather indicates the need for a preliminary screening by which elder men have a greater chance of showing a free or bioavailable testosterone concentration below reference ranges (7). Our findings agree with those in the literature (1). The AMS scale was designed to assess symptoms of aging (independent of those that are disease-related) between groups of males under different conditions, to evaluate the severity of symptoms over time, and to measure changes pre- and post androgen replacement therapy (10). When the AMS questionnaire was compared to ADAM for screening hypogonadism (22), a sensitivity of $83 \%$ was achieved but the specificity was only $39 \%$, using a very low threshold for AMS, a score of only 17 points.

Regarding the ADAM scale, according to our attempt for an alternative validation, only ADAM 1 could be used as a screening tool for hypogonadism. In fact it was the only ADAM criterion that correlated with $\mathrm{LOH}$ laboratorial diagnosis in our sample. The first question in the ADAM questionnaire, "Do you have a decrease in libido (sex drive)?" was the most useful in screening for hypogonadism, with a sensitivity of $77.5 \%$ and a specificity of $43.9 \%$. The other criteria that corresponded to a positive ADAM rating, however, correlated with neither the laboratory diagnosis of hypogonadism nor with the testosterone levels. Using ADAM l, we observed sensitivity similar to that obtained for any ADAM criteria in other populations (77.5\% versus $80-88 \%$, respectively). The specificity for ADAM 1 in our study $(43.9 \%)$ was intermediate between that reported for any ADAM criteria in Canadian (60\%), Belgian (21.6\%) and Taiwan (20\%) men (11, 23, and 24).

One way to explain the different results generally found regarding ADAM and AMS was demonstrated by Ichioka et al. (25) which examined 2211 men, 86\% above the age of 40 . In this study, hypogonadism better correlated with sexuality, as measured by the sexual sub-score, than with the total AMS score (25). Similar results were found in the Belgian study by T'sjoen et al. (26). Delhez et al. also described that the psychological response to decreased androgen manifests as minor depressive symptoms, which are not pathological (27). The AMS scale adds three different dimensions, therefore diluting the results and generating a poor comparison with the ADAM questionnaire, which needs, in most cases, only one affirmative answer to yield a positive rating.

In our study, using AMS and ADAM-based criteria, $179(84 \%)$ and $128(60 \%)$ of the 216 subjects, respectively, would be suspected of hypogonadism. Using 
the recommended laboratory criteria, only 41 (19\%) of the subjects were judged hypogonadal after a second cFT exam, 28 in the osteoporosis group (25\%) and 13 in the normal bone density group (12.2\%). These numbers show that both questionnaires lack specificity. If applied to the general population, they would result in a large number of negative laboratory exams. Our findings support the Endocrine Society guidelines (5), in that questionnaires have not demonstrated to be a costeffective strategy to detect $\mathrm{LOH}$, and hormonal dosages should rather be performed in high risk individuals, such as osteoporotic men.

If only a positive response to the first ADAM question along with two samples of cFT $<6.5 \mathrm{ng} / \mathrm{dl}$ was considered, hypogonadism would be diagnosed only in $31(15 \%)$ of the men. So, even the clinical criterion that demonstrated a better sensitivity and specificity overall, was not able to identify all men with laboratory-defined hypogonadism (Table 2), because some men denied diminished sexual desire and presented different complaints. This demonstrates the complexity of the clinical picture of late-onset hypogonadism and the necessity of using more than a single criterion or question for the clinical evaluation.

Sexuality combines libido and sexual function, and can be related to race, culture and religion. The IIEF- 5 questionnaire, which was used to evaluate the association of sexual dysfunction and hypogonadism, did not demonstrate any correlation with laboratory hypogonadism or testosterone levels in our study. The IIEF-5 is an abridged five item version of the fifteen item International Index of Erectile Function (IIEF), an important questionnaire for the evaluation of sexual erection that has an excellent sensitivity (98\%) and good specificity (88\%) (11).

Although Chinese cohort studies have tried to establish androgen deficiency risks by using the IIEF- 5 (28), in the majority of studies (29-31) including the Massachusetts Male Aging Study (MMAS), this correlation was not demonstrated (32). A possible explanation for the differences in these results was suggested in Mikhail's review (33). A conclusive diagnosis of hypogonadism in men in these studies cannot be confirmed, because many studies suffered from the lack of a second testosterone sample, which was collected in our study. His conclusion is that in most men, circulating levels of testosterone well below the normal range become essential for normal erections, and therefore only a pronounced hypogonadism would be evidenced by erectile dysfunction (33). Additionally, ED becomes very common with advancing age, again as observed in our study. The great majority of hypothesized causes relate to vascular pathology, diabetes, hypertension and the use of drugs (34), and only in some cases, hypogonadism (35).

\section{CONCLUSIONS}

The prevalence of late-onset hypogonadism was $25 \%$ in men with osteoporosis and $12.2 \%$ in men with normal bone density over 50 years of age (OR 2.08; IC95\%: 1.14-3.79 for hypogonadism in osteoporotic men).

The symptom that best correlated with $\mathrm{LOH}$ was decreased sexual desire or libido (ADAM l positive). Among hypogonadal men, the lower the calculated free testosterone, the greater was the prevalence of a positive answer to ADAM 1.

AMS scores $\geq 27$ correlated only with TT levels less than $400 \mathrm{ng} / \mathrm{dl}$.

Erectile dysfunction of any degree varied from 58 to $84 \%$, and increased in both prevalence and severity with age. There were no correlations between testosterone levels or hypogonadism and erectile dysfunction.

Acknowledgements: The authors thank the Diagnósticos da América Laboratory and the Instituto Fernandes Figueira, which kindly performed the sample measurements. At the Instituto Fernandes Figueira, special thanks to Jânio Alves Cordeiro (Head of the Department of Clinical Pathology), Marcio Guilherme de Souza (technician responsible for the hormonal analysis) and Rodrigo Batista dos Santos (technician responsible for the blood collection and sampling). In addition, we thank Martha Suárez-Mutis, epidemiology doctor of IOC-Fiocruz, for the statistical analysis and Sergio Koifman, chief professor of the Post Graduate Program of Public Health and Environment of the National School of Public Health/Fiocruz for the suggestions during the study and for the review of this manuscript. There is no conflict of interest of any author that could prejudice the impartiality of the scientific work.

\section{REFERENCES}

1. Tsujimura A, Matsumiya $K$, Miyagawa $Y$, Takao $T$, Fujita $K$, Takada S, et al. Comparative study on evaluation methods for serum testosterone level for PADAM diagnosis. Int J Impot Res. 2005;17:259-63.

2. Morales A, Lunenfeld B. Investigation, treatment and monitoring of late-onset hypogonadism in males. Official recommendations of ISSAM. International Society for the Study of the Aging Male. Aging Male. 2002;5:74-86. 
3. Rosner W, Auchus RJ, Azziz R, Sluss PM, Raff H. Position statement: utility, limitations, and pitfalls in measuring testosterone: an endocrine society position statement. J Clin Endocrinol Metab. 2007;92:405-13.

4. Haren MT, Kim MJ, Tariq SH, Wittert GA, Morley JE. Andropause: a quality-of-life issue in older males. Med Clin North Am. 2006;90:1005-23.

5. Bhasin S, Cunningham GR, Hayes FJ, Matsumoto AM, Snyder PJ, Swerdloff RS, et al. Testosterone therapy in adult men with androgen deficiency syndromes: an endocrine society clinical practice guideline. J Clin Endocrinol Metab. 2006;91:1995-2010.

6. Celec P, Ostatníková D. Testosterone: an overview; insights into its physiology and clinical implications. Int J Endocrinol Metab. 2003;2:84-96.

7. Mooradian AD, Korenman SG. Management of the cardinal features of andropause. Am J Ther. 2006;13:145-60.

8. Nieschlag E, Swerdloff R, Behre HM, Gooren LJ, Kaufman JM, Legros JJ, et al. Investigation,treatment and monitoring of late-onset hypogonadism in males ISA, ISSAM, and EAU Recommendations. Eur Urol. 2005;48:1-4.

9. Morley JE, Charlton E, Patrick P, Kaiser FE, Cadeau P, McCready $D$, et al. Validation of a screening questionnaire for androgen deficiency in aging males. Metabolism. 2000;49:1239-42.

10. Heinemann LA, Saad F, Zimmermann T, Novak A, Myon E, Badia $X$, et al. The Aging Males' Symptoms (AMS) scale: update and compilation of international versions. Health Qual Life Outcomes. 2003;1:15.

11. Rosen RC, Cappelleri JC, Smith MD, Lipsky J, Pena BM. Development and evaluation of an abridged, 5-item version of the International Index of Erectile Function (IIEF-5) as a diagnostic tool for erectile dysfunction. Int J Impot Res. 1999;11:319-26.

12. Heinemann LAJ, Zimmermann T, Vermeulen A, Thiel C. A new 'Aging Males' Symptoms' (AMS) rating scale. Aging Male. 1999;2:105-14.

13. Moore C, Huebler D, Zimmermann T, Heinemann LA, Saad F, Thai DM. The Aging Males' Symptoms Scale (AMS) as outcome measure for treatment of androgen deficiency. Eur Urol. 2004;46:80-7.

14. Heinemann LA, Moore C, Dinger JC, Stoehr D. Sensitivity as outcome measure of androgen replacement: the AMS scale. Health Qual Life Outcomes. 2006;30;4:23.

15. Rosen RC, Riley A, Wagner G, Osterloh IH, Kirkpatrick J, Mishra $A$. The international index of erectile function (IIEF): a multidimensional scale for assessment of erectile dysfunction. Urology. 1997;49:822-30.

16. Rhoden EL, Lemos RR, Riedner CE, Telöken C, Souto CAV. Validade do índice internacional de função erétil (IIEF) e IIEF-5 simplificado na avaliação da função eretiva. Braz J Urol. 2001;27 Suppl 1:18.

17. Vermeulen A, Verdonck L, Kaufman JM. A critical evaluation of simple methods for the estimation of free testosterone in serum. J Clin Endocrinol Metab. 1999;84:3666-72.

18. Kaufman JM, Vermeulen A. The decline of androgen levels in elderly men and its clinical and therapeutic implications. Endocr Rev. 2005;26:833-76.

19. Kelleher S, Conway AJ, Handelsman DJ. Blood testosterone threshold for androgen deficiency symptoms. J Clin Endocrinol Metab. 2004;89:3813-17.
20. Matsumoto AM. Andropause: clinical implications of the decline in serum testosterone levels with aging in men. J Gerontol A Biol Sci Med Sci. 2002;57:M76-99.

21. Morley JE. The need for a men's health initiative. J Gerontol A Biol Sci Med Sci. 2003;58:614-7.

22. Morley JE, Perry HM, Kevorkian RT, Patrick P. Comparison of screening questionnaires for the diagnosis of hypogonadism. Maturitas. 2006;53:424-9.

23. Tancredi A, Reginster JY, Schleich F, Pire G, Maassen P, Luyckx $F$, et al. Interest of the androgen deficiency in aging males (ADAM) questionnaire for the identification of hypogonadism in elderly community-dwelling male volunteers. Eur J Endocrinol. 2004;151:355-60.

24. Lin YC, Hwang TI, Chiang HS, Yang CR, Wu HC, Wu TL, et al. Correlations of androgen deficiency with clinical symptoms in Taiwanese males(Abstract). Int J Impot Res. 2006;18:343-7.

25. Ichioka K, Nishiyama H, Yoshimura K, Itoh N, Okubo K, Terai A. Aging males' symptoms scale in japanese men attending a multiphasic health screening clinic. Urology. 2006;67:589-93.

26. T'Sjoen G, Goemaere S, De Meyere M, Kaufman JM. Perception of males' aging symptoms, health and well-being in elderly community-dwelling men is not related to circulating androgen levels. Psychoneuroendocrinology. 2004;29:201-14.

27. Delhez M, Hansenne M, Legros J-J. Andropause and psychopathology: minor symptoms rather than pathological ones. Psychoneuroendocrinology. 2003;28:863-74.

28. Wong SYS, Chanb DCC, Hong A, Wooa J. Prevalence of and risk factors for androgen deficiency in middle-aged men in Hong Kong. Metabolism. 2006;55:1488-94.

29. Rhoden EL, Teloken C, Sogari PR, Souto CAV. The relationship of serum testosterone to erectile function in normal aging men. J Urol. 2002;167:1745-48.

30. Christ-Crain M, Mueller B, Gasser TC, Kraenzlin M, Trummler $\mathrm{M}$, Huber $\mathrm{P}$, et al. Is there a clinical relevance of partial androgen deficiency in the aging male? J Urol. 2004;172:624-27.

31. Bhasin S, Woodhouse L, Casaburi R, Singh AB, Bhasin D, Berman $\mathrm{N}$, et al. Testosterone dose-response relationships in healthy young men. Am J Physiol Endocrinol Metab. 2001;281: E1172-81.

32. Feldman HA, Goldstein I, Hatzichristou DG, Krane RJ, McKinlay JB. Impotence and its medical and psychological correlates: results of the Massachusetts Male Aging Study. J Urol. 1994; 151:54-61.

33. Mikhail N. Does testosterone have a role in erectile function? Am J Med. 2006;119:373-82.

34. Fine SR. Erectile dysfunction and comorbid diseases, androgen deficiency, and diminished libido in men. J Am Osteopath Assoc. 2004;104 Suppl 1:S9-15.

35. Carbone DJ, Seftel AD. Erectile dysfunction. Diagnosis and treatment in older men. Geriatrics. 2002;57(9):18-24.

\section{Correspondence to:}

Daniel Jorge de Castro Braga

Avenida Epitácio Pessoa 3540, ap. 503.

22471-003 Rio de Janeiro RJ

E-mail: doctordaniel@uol.com.br 